\title{
RANCANG BANGUN APLIKASI PENERIMAAN SISWA BARU BERBASIS WEB MENGGUNAKAN FRAMEWORK CODEIGNITER
}

\author{
Regina Nurfitriyani Anissa', Rizki Tri Prasetio² \\ ${ }^{1}$ Universitas Adhirajasa Reswara Sanjaya \\ e-mail: reginanurfitriyanianissa@gmail.com \\ 2Universitas Adhirajasa Reswara Sanjaya \\ e-mail: rizki@ars.ac.id
}

\begin{abstract}
Abstrak
Kemajuan teknologi baru-baru ini berkembang sangat cepat serta dapat menjawab tantangan hambatan. Salah satu bentuk pemanfaatan teknologi dapat digunakan dalam bidang Pendidikan dengan menggunakan konsep teknologi web-based application. SMK Ma'arif Cicalengka merupakan sekolah menengah kejuruan yang cukup favorit di wilayah Cicalengka Kabupaten Bandung yang saat ini belum memanfaatkan perkembangan teknologi secara maksimal, segala aktifitas yang menyangkut keperluan sekolah dan siswa dilakukan secara konvensional, salah satunya pendaftaran siswa baru dimana para calon siswa dan walinya diharuskan datang langsung ke sekolah. Penelitian bertujuan untuk mempermudah mekanisme penerimaan siswa baru menjadi sistem yang terkomputerisasi berbasis web menggunakan framework codeigniter. Model pengembangan yang digunakan dalam pengembangan aplikasi menggunakan model waterfall. Hasil dari penelitian yaitu pembuatan aplikasi penerimaan siswa baru berbasis web yang dapat di akses langsung oleh pihak sekolah dan calon siswa baru yang akan mendaftar ke SMK Ma'arif Cicalengka. Dengan adanya aplikasi ini diharapkan pelaksanaan penerimaan siswa baru diharapkan menjadi lebih transparan dan akomodatif.
\end{abstract}

Kata kunci: Penerimaan siswa baru, Codeigniter, Model Waterfall.

\begin{abstract}
Current technological advances have developed very rapidly and are able to answer the challenges of obstacles. One form of technology utilization can be used in the field of education by using the concept of web-based application technology. Vocational Ma'arif Cicalengka is one of the vocational high schools in the Cicalengka area, Bandung Regency. Which currently has not taken full advantage of technological developments, all activities related to school and student needs are still carried out manually, one of which is the registration of new students where prospective students and their guardians are required to come directly to school. This study aims to simplify the new student admission system into a web-based computerized system using a codeigniter framework. The method used in the development of this information system is the waterfall method. The results of this study are the creation of a web-based information system for new student admissions that can be accessed directly by the school and prospective new students who will register at Vocational Ma'arif Cicalengka. With this information system, it is hoped that the implementation of new student admissions is expected to be more transparent and accommodating with the new student admission information system implemented in this school.
\end{abstract}

Keywords: Student adminission, Codeigniter, Waterfall model. 


\section{Pendahuluan}

Kecanggihan teknologi saat ini mampu menjawab tantangan hambatan serta berkembang cukup pesat (Prasetio et al., 2018). Internet sendiri merupakan bentuk maya dari dunia ini yang saat ini dapat membentuk kehidupan yang baru semenjak kehadirannya (Prasetio et al., 2018). Informasi yang tepat, akurat dan cepat menjadi tuntutan utama bagi penerimanya karena kebutuhan akan informasi sangat penting (Eviani, Rizki, \& Pratiwi, 2016). Salah satu bentuk pemanfaatan teknologi dapat digunakan dalam bidang Pendidikan dengan menggunakan konsep teknologi web-based application (Mubarok \& Kurniawan, 2015). Inovasi pendidikan akan terus berkembang (Mubarok et al., 2018). Inovasi tersebut daintaranya pencarian sumber belajar yang lebih mudah, serta penggunaan media dan multimedia sebagai media pembelajaran (Budiman, 2014). Sekolah sebagai Lembaga Pendidikan yang merupakan satu kesatuan dari pribadipribadi yang berinteraksi di masyarakat, pendidikan baru dapat dikatakan berhasil apabila terdapat dukungan yang penuh dari masyarakat serta keluarga. Sistem sekolah dapat terwujud karena munculnya cara interaksi yang khas (Mesiono \& Asrul, 2012). SMK Ma'arif Cicalengka merupakan sekolah menengah kejuruan swasta di wilayah Kabupaten Bandung lebih tepatnya di Cicalengka. Perkembangan teknologi saat ini belum dimanfaatkan secara maksimal oleh SMK Ma'arif Cicalengka, segala aktifitas yang menyangkut keperluan sekolah dan siswa dilakukan secara konvensional, salah satunya pendaftaran siswa baru dimana para calon siswa dan walinya diharuskan datang langsung ke sekolah untuk mengambil formulir dan mengumpulkan serta berkas pendaftaran. Hal itu mengakibatkan adanya kendala karena terjadi penumpukan permintaan siswa baru yang akan mendaftar sehingga pihak sekolah kewalahan.

Penerimaan siswa baru merupakan tahapan awal seleksi untuk penyaringan siswa baru sesuai kriteria yang ditentukan baik secara administratif maupun kompetitif (Dzulhaq, Sutarman, \& Wulandari, 2017). Menurut Khakim Ghozali dalam jurnal (Juhartini, Arwidiyarti, \& Ramlan, 2017) memaparkan Penerimaan Siswa Baru (PSB) proses administrasi secara berkala sesuai periode tahun akademik baru untuk menyeleksi calon siswa menggunakan kriteria-kriteria tertentu seperti nilai dan berkas administrasi.

Penelitian mengenai perancangan web penerimaan siswa baru sebelumnya pernah dilakukan dengan menggunakan metode prototype. Dalam penelitian tersebut, web penerimaan siswa baru dapat memberikan kemudahan dan ketersediaan akses data dan informasi dalam proses pendaftaran siswa baru (Witanto \& Solihin, 2016). Selanjutnya web penerimaan siswa baru menggunakan metode waterfall dengan framework laravel, dapat membantu sekolah serta wali siswa dalam proses pendaftaran serta menampilkan informasi mengenai pendaftaran (Jabbar, Puspita, \& Indriawan, 2019).

Penulis membuat aplikasi penerimaan siswa baru ini berbasis website, dengan menggunakan model pengembangan waterfall sebagai pengembangan sistem dan dalam membangun website penulis menggunakan framework codeigniter. Framework Codeigniter merupakan salah satu kerangka kerja yang dirancang untuk mengembangkan aplikasi berbasis website dengan cepat dan mudah, dengan codeigniter kita cukup fokus pada pengembangan project dan meminimalisir jumlah kode yang akan ditulis (Subagia, 2018).

\section{Metode Penelitian}

Metode penelitian meliputi tahapan penelitian yang digunakan dalam dalam penelitian ini berdasarkan model pengembangan Waterfall.

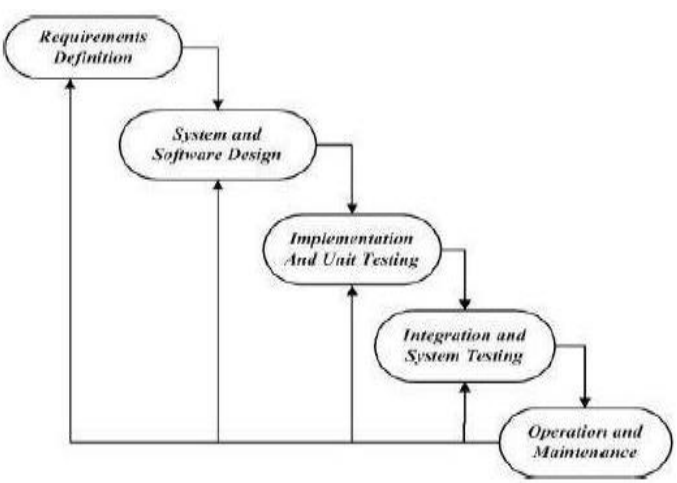

Gambar 1. Metode Waterfall

Sumber: (Destiningrum \& Adrian, 2017)

Model Waterfall merupakan salah satu model pengembangan sistem yang menganut planning driven dimana semua 
tahapan haruslah direncanakan dan terencana.

\section{Analisa Kebutuhan Perangkat Lunak}

Tahapan pertama membangun aplikasi menggunakan model waterfall dilakukan dengan menganalisis sistem yang berjalan saat ini dan spesifikasi kebutuhan perangkat lunak yang dibutuhkan berdasarkan permasalahan yang ada. Seperti pengisian formulir pendaftaran masih ditulis di kertas lembar formulir, calon siswa baru merasa kurang mendapatkan informasi mengenai pendaftaran siswa baru, dan pihak sekolah juga kesulitan dalam memproses pendaftaran siswa baru.

Dalam pengumpulan data dan informasi untuk melengkapi kebutuhan pengembangan aplikasi, dilakukan dengan cara:

1. Wawancara

Dilakukan wawancara dengan staff sekolah untuk mendapatkan informasi mengenai penerimaan siswa baru, seperti apa persyaratan yang dibutuhkan untuk pendaftaran siswa baru, serta informasi mengenai biaya dan waktu pendaftaran.

2. Studi Pustaka

Studi pustaka dimaksudkan untuk mencari konsep dan teori yang relevan terhadap masalah yang dihadapi. Referensi yang relevan didapat dari artikel yang diterbitkan pada jurnal nasional terkemuka serta dari buku referensi.

\section{Desain Software dan Sistem}

Tahapan desain perangkat lunak dilakukan dengan membuat desain pemodelan sistem dan desain basis data. Berikut penjelasannya:

1. Desain Perangkat Lunak

Pemodelan sistem perangkat lunak, penulis menggunakan beberapa contoh dari alat bantu perancangan berorientasi objek berbasis Unified Modeling Language, diantaranya:

a. Use Case Diagram digunakan untuk mengetahui apa saja yang dapat dilakukan oleh sistem serta apa saja yang mungkin dilakukan oleh pengguna terhadap sistem. Dalam Dalam aplikasi yang akan dikembangkan, terdapat dua pengguna yang dapat mengakses aplikasi yakni, pengguna dan pengelola. b. Activity Diagram digunakan untuk menggambarkan alur aktifitas bagi setiap fitur dan fungsi aplikasi.

c. Sequence Diagram digunakan untuk menggambarkan relasi serta hubungan antar objek yang terlibat dalam aplikasi dengan mendeskripsikan pesan yang dikirim yang diterima oleh masing-masing objek.

d. Class Diagram, digunakan untuk menggambarkan hubungan antar kelas yang terlibat dalam aplikasi.

2. Desain Basis Data

Pada tahap ini, penulis menggunakan Entity Relationship Diagram (ERD) digunakan untuk menggambarkan hubungan serta relasi antar entitas yang terlibat dalam aplikasi. ERD menggunakan user sebagai objek dasar atau entitas dan hubungan atau relation dari user tersebut adalah melakukan dengan objek lainnya yaitu pendaftaran siswa baru.

3. Desain Antar Muka

Pada desain antarmuka membahas tentang rancangan antarmuka sistem informasi sebagai media komunikasi antara pengguna dan perangkat lunak.

\section{Implementasi}

Dalam tahapan Implementasi, desain yang telah dibuat sebelumnya diterjemahkan ke dalam bahasa pemrograman, dalam hal ini diterjemahkan kedalam bahasa pemrograman server-side $P H P$. Selain itu juga rancangan basis data yang telah dibuat diimplementasikan kedalam basis data.

\section{Pengujian Sistem}

Dalam tahapan pengujian sistem, dilakukan yaitu dengan cara menguji keseluruhan sistem informasi pendaftaran siswa baru yang telah dibuat. Metode pengujian yang digunakan terhadap aplikasi yang telah dibangun menggunakan metode black box. Black box berfokus dalam menguji fungsionalitas, serta hasil dari proses komputasi aplikasi kemudian disesuaikan dengan fungsi yang seharusnya ada pada aplikasi tanpa mengetahui apa yang sesungguhnya terjadi secara detil. Dalam arti lain, hanya berfokus pada masukan dan luaran saja (Dhuha, 2018).

\section{Operasional dan Pemeliharaan}

Tahapan terakhir dari model waterfall adalah operasional dan 
pemeliharaan. Tahap ini digunakan untuk mengakomodir perawatan serta perbaikan pada perangkat lunak yang telah dihasilkan.

\section{Hasil dan Pembahasan}

Hasil dan pembahasan membahas hasil secara komprehensif, dimana akan menyajikan hasil dari tahapan-tahapan yang telah dilakukan sebelumnya. Serta menyajikan hasil dari perangkat lunak yang telah dikembangkan.

\subsection{Analisa Kebutuhan Perangkat Lunak}

Analisa kebutuhan perangkat lunak berisi spesifikasi fungsionalitas aplikasi yang akan dibangun. Spesifikasi fungsionalitas tersebut berdasarkan analisa kebutuhan pengguna. Dalam aplikasi yang dikembangkan akan dibagi menjadi dua pengguna utama yakni, pengguna dan pengelola. Berikut ini spesifikasi kebutuhan dari sistem informasi ini:

A. Kebutuhan Sistem Halaman Pengelola

A1. Pengelola dapat masuk ke dalam sistem

A2. Pengelola dapat mengupdate data profil

A3. Pengelola dapat mengelola data pengguna

A4. Pengelola dapat mengelola data pendaftar

A5. Pengelola dapat mencetak bukti pendaftaran

A6. Pengelola dapat keluar dari aplikasi

B. Kebutuhan Sistem Halaman Pengguna (Calon/Wali Siswa)

B1. Pengguna dapat melakukan registrasi

B2. Pengguna dapat masuk ke dalam sistem

B3. Pengguna dapat mengakses halaman home, informasi, about, contact

B4. Pengguna dapat memperbaharui data profil

B5. Pengguna dapat melakukan pendaftaran

B6. Pengguna dapat mencetak bukti pendaftaran

B7. Pengguna dapat keluar dari sistem

\subsection{Desain Sistem}

\subsubsection{Desain Perangkat Lunak}

1. Use Case Diagram Pengelola

Use case diagram pengelola ini menjelaskan dan menggambarkan fitur sesuai kebutuhan pengelola sistem informasi penerimaan siswa baru. Seperti login, mengupdate profil, mengelola data user, mengelola data pendaftaran, mencetak bukti pendaftaran dan logout. Berikut ini use case diagram pengelola pada sistem informasi penerimaan siswa baru:

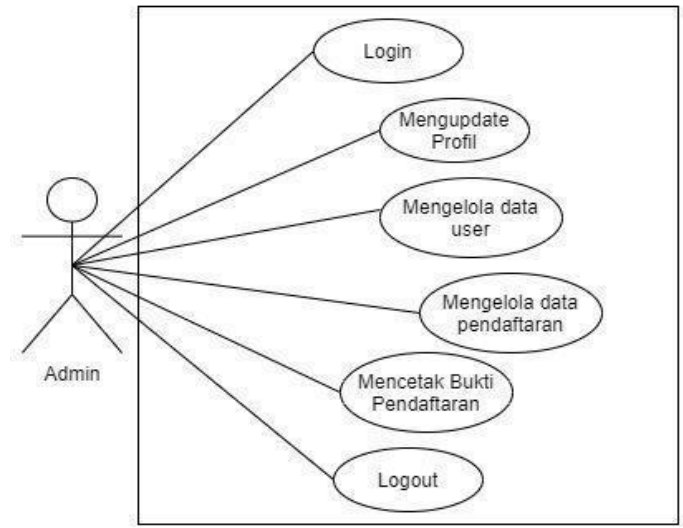

Gambar 2. Use Case Diagram Pengelola

2. Use Case Diagram Pengguna

Use case diagram pengguna ini menjelaskan dan menggambarkan fitur sesuai kebutuhan pengguna pada sistem informasi penerimaan siswa baru. Seperti login, registrasi, melakukan pendaftaran, melihat informasi, mencetak bukti pendaftaran, mengedit profil, dan logout. Berikut ini rancangan dari use case diagram pengguna pada sistem informasi penerimaan siswa baru:

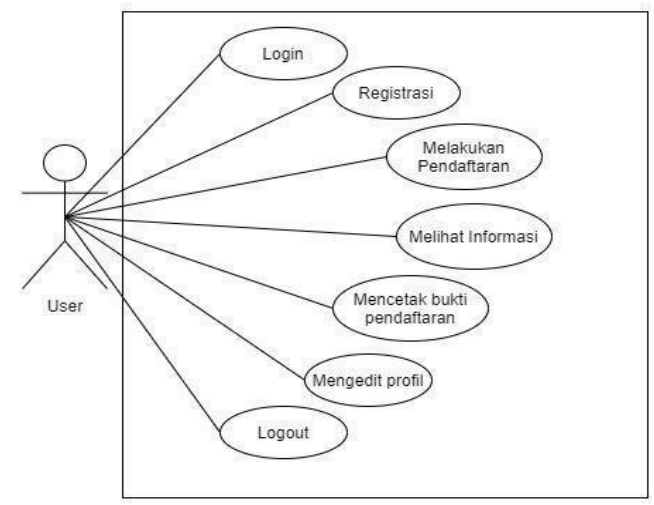

Gambar 3. Use Case Diagram Pengguna

\subsubsection{Desain Basis Data}

Dalam mendesain basis data, digunakan Entity Relationship Diagram (ERD). ERD menjelaskan entitas yang terlibat dalam aplikasi yang telah dikembangkan serta hubungan antara entitas-entitasnya. Rancangan dari ERD aplikasi ini dapat dilihat pada Gambar 4. 


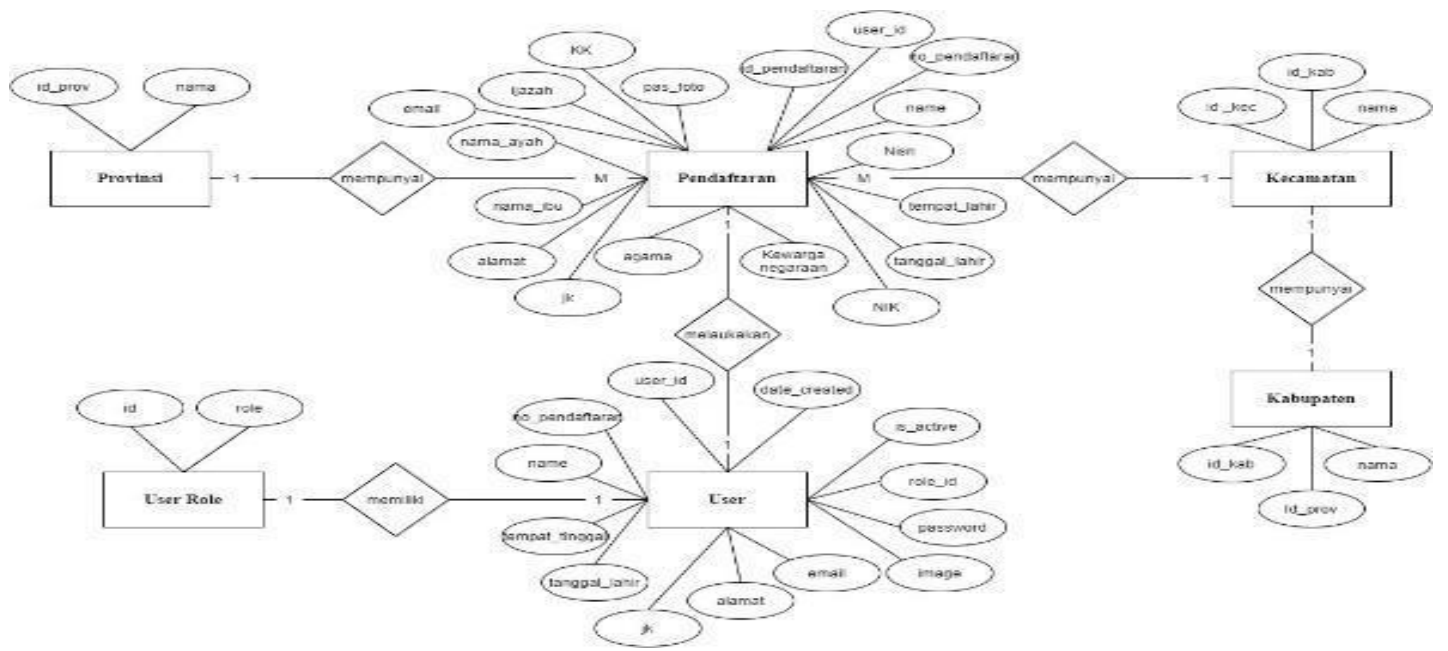

Gambar 4. Entity Relationship Diagram

\subsubsection{Desain Antarmuka}

Pada tahap ini penulis akan menampilkan halaman registrasi, login, home, formulir pendaftaran, data formulir pendaftaran, cetak bukti, dan halaman kelola pendaftaran admin.

1. Halaman Registrasi

Bagi pengguna yang belum memiliki akun untuk masuk kedalam aplikasi, maka perlu diminta untuk mengisi halaman registrasi. Berikut desain antar muka dari halaman registrasi:

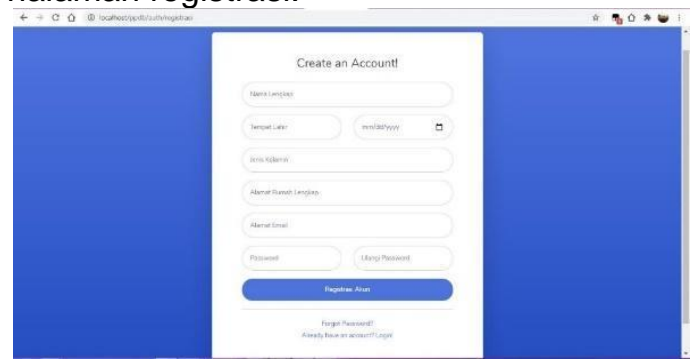

Gambar 5. Tampilan Halaman Registrasi

\section{Halaman Login}

Halaman login digunakan sebagai autentikasi pengguna yang akan mengakses aplikasi penerimaan siswa baru ini. Berikut desain antarmuka halaman login:

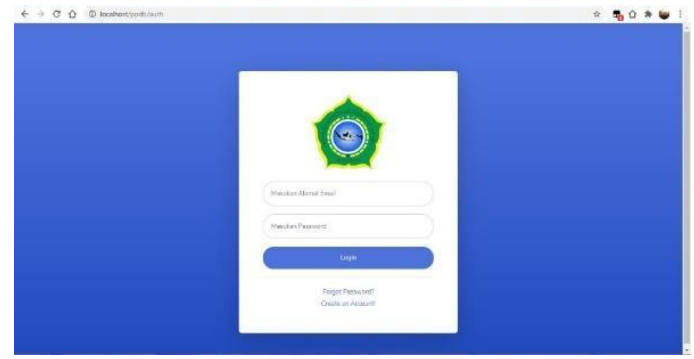

Gambar 6. Tampilan Halaman Login
3. Halaman Beranda

Pada halaman beranda, user dapat melihat tata cara pendaftaran dan mengakses fitur yang tersedia pada sistem informasi penerimaan siswa baru ini. Berikut desain antarmuka halaman home:

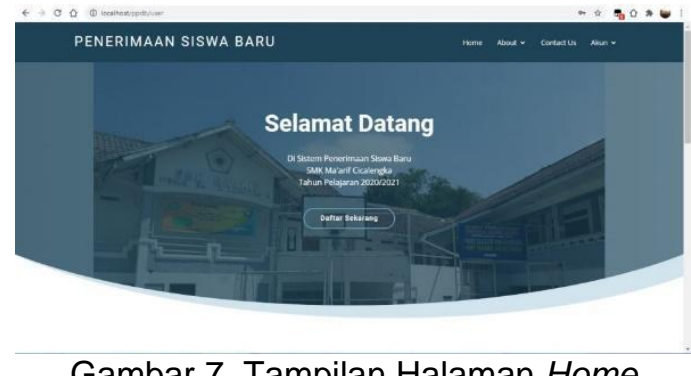

Gambar 7. Tampilan Halaman Home

4. Halaman Formulir Pendaftaran

Pengguna yang akan melakukan pendaftaran dapat mengisi formulir pendaftaran yang tersedia pada halaman pendaftaran. Berikut desain antarmuka halaman pendaftaran:

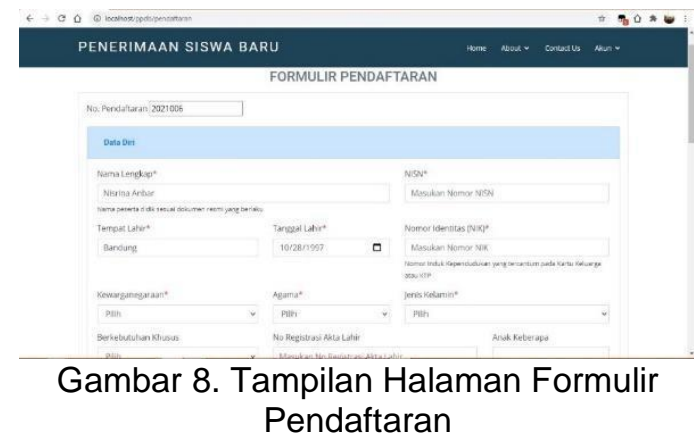

5. Halaman Data Formulir Pendaftaran

Setelah Pengguna mengisi formulir pendaftaran, user langsung diarahkan ke halaman data formulir pendaftaran dan dapat melihat data yang sebelumnya telah 
diisi. Berikut desain antar muka dari halaman pendaftaran:

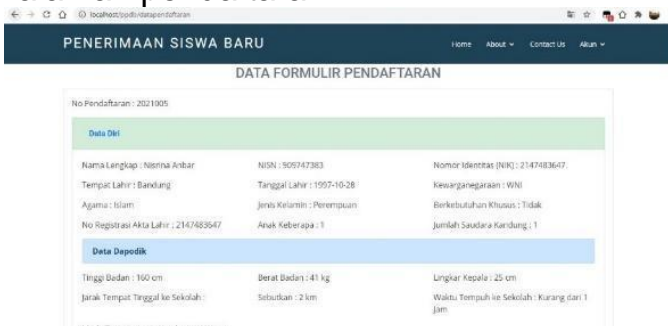

Gambar 9. Tampilan Halaman Data Formulir Pendaftaran

6. Halaman Kelola Data Pendaftaran

Pengelola yang akan mengelola data pendaftaran seperti menghapus, dan mengupdate dapat melakukannya di halaman Kelola data pendaftaran. Berikut desain antar muka dari halaman Kelola data pendaftaran:

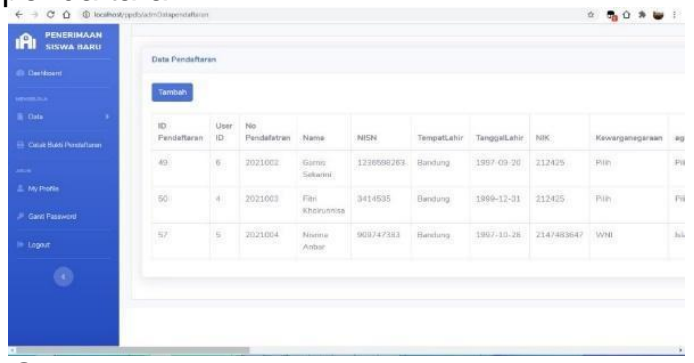

Gambar 10. Tampilan Halaman Kelola Data Pendaftaran

\subsection{Implementasi}

Tahap implementasi merupakan tahap mengimplementasikan semua rancangan yang telah dibuat ke dalam bentuk kode bahasa pemrograman yang dapat dimengerti oleh komputer. Untuk mengimplementasikan rancangan, penulis menggunakan alat pendukung sebagai berikut:

1. Perangkat Lunak Penunjang

a. Sistem Operasi Windows 8.1 Pro (64bit)

b. Sublime Text 3 v3.1.1

c. Xampp v3.2.2 (32-bit)

d. Framework Codelgniter 3

e. Google Chrome v83.0.4103.106 (32bit)

2. Perangkat Keras Penunjang
a. Processor Intel® Bay Trail-M Dual Core Celeron N2840 Processor
b. Memori SDRAM $2 \mathrm{~GB}$
c. Monitor 14.0" Auto HD

3. Bahasa Pemrograman
a. PHP v7.3.2
b. $\operatorname{css} 4$

\section{c. HTML5}

\subsection{Pengujian Sistem}

Pada tahap pengujian sistem dilakukan dengan cara pengujian keseluruhan sistem informasi pendaftaran siswa baru. Metode pengujian sistem yang digunakan penulis dalam penelitian ini yaitu metode black box. Pengujian dengan menggunakan metode black box berfokus pada fungsionalitas dari sebuah sistem. Dalam pengujiannya, pertama membuat test case untuk menguji setiap fungsi yang ada pada sistem tersebut, dan membuat test case untuk menguji apakah alur kerja suatu fungsi pada sistem informasi tersebut sudah sesuai dengan kebutuhan yang diperlukan oleh pengguna.

\subsection{Operasional}

Pada tahapan operasional dan pemeliharaan, sistem yang dibangun siap digunakan untuk menjalankan alur pendaftaran siswa baru pada SMK Ma'arif Cicalengka. Untuk saat ini, jaringan yang digunakan dalam menjalankan sistem informasi ini adalah jaringan lokal atau intranet.

\section{Kesimpulan}

Dalam penelitian ini telah diuraikan perancangan serta pembuatan aplikasi penerimaan siswa baru pada SMK Ma'arif Cicalengka berbasis web, maka dapat ditarik kesimpulan dari penelitian ini sebagai berikut:

1. Aplikasi Peneriman Siswa Baru dapat digunakan oleh pengelola diantaranya panitia penerimaan siswa baru untuk mengelola data pendaftaran dan juga calon siswa untuk melakukan pendaftaran pada SMK Ma'arif Cicalengka dengan lebih mudah dan secara komputerisasi.

2. Calon atau wali siswa yang akan mendaftar dapat melihat informasi mengenai pendaftaran siswa baru dengan lengkap di sistem informasi ini

3. Penyimpanan data pendaftaran tidak mudah mengalami kerusakan karena telah tersimpan dalam database sistem informasi.

\section{Referensi}

Budiman, H. (2014). Peran Teknologi Informasi Dan Komunikasi Dalam Pendidikan. Al-Tadzkiyyah: Jurnal Pendidikan Islam, 8(I), 31-43. 
Destiningrum, M., \& Adrian, Q. J. (2017). Sistem Informasi Penjadwalan Dokter Berbasis Web Dengan Menggunakan Framework Codeigniter (Studi Kasus: Rumah Sakit Yukum Medical Centre ). 11(2), 30-37.

Dzulhaq, M. I., Sutarman, \& Wulandari, S. (2017). Sistem Pendukung Keputusan Penerimaan Siswa Baru dengan Metode Simple Additive Weighting di SMK Kusuma Bangsa. SISFOTEK GLOBAL, 7(2).

Eviani, S., Rizki, S. D., \& Pratiwi, M. (2016). Sistem Informasi Penerimaan Siswa Baru Berbasis Web Pada Smpn 34 Kabupaten Tebo. Universitas Putra Indonesia YPTK Padang, (1), 1-7.

Jabbar, M. A., Puspita, R., \& Indriawan, H. (2019). Sistem Informasi Pendaftaran Siswa Studi Kasus Smk Ma'arif AlMizan. Seminar Nasional Informatika Dan Aplikasinya (SNIA), (September), 1-3. Bandung.

Juhartini, Arwidiyarti, D., \& Ramlan. (2017). Sistem Informasi Penerimaan Siswa Baru Berbasis Web Pada MA. Darul Qur'an Bengkel. Explore STMIK Mataram, 7(2), 6-12.

Mesiono, S., \& Asrul. (2012). INOVASI PENDIDIKAN (Suatu Analisis Terhadap Kebijakan Baru Pendidikan) (C. U. Wijaya, ed.). Medan: Perdana Publishing.

Mubarok, A., \& Kurniawan, M. C. (2015). Aplikasi Ujian Online Pada SMK Ma , Arif Bandung Berbasis Web. II(1), 332344.

Mubarok, A., Riana, D., Sanjaya, R., Prasetio, R. T., Ramdhani, Y., Rismayadi, A. A., ... \& Herliana, A. (2018). Sistem Informasi Pelayanan Online di Mapolresta Bandung. Jurnal Abdimas BSI: Jurnal Pengabdian Kepada Masyarakat, 1(1).

Prasetio, R. T., Ramdhani, Y., Anshori, I. F., Rismayadi, A. A., Hidayatulloh, S., \& Mubarok, A. (2018). Analisis Penerimaan Microsoft Office dengan Pendekatan Technology Acceptance Model pada Warga Desa Karyamukti Kecamatan Cililin. Jurnal Abdimas BSI: Jurnal Pengabdian Kepada Masyarakat, 1(3).

Prasetio, R. T., Mubarok, A., Ramdhani, Y., Junianto, E., Rismayadi, A. A., Anshori, I. F., ... \& Topiq, S. (2018). Upaya peningkatan produktivitas UMKM melalui implementasi ICT pada look at hijab Bandung. Jurnal Abdimas BSI: Jurnal Pengabdian Kepada Masyarakat, 1(1).

Subagia, A. (2018). Kolaborasi Codeigniter dan Ajax dalam Perancangan CMS (nadhia@alexmedia.id, ed.). Jakarta: PT Elex Media Komputindo.

Witanto, R., \& Solihin, H. H. (2016). Perancangan Sistem Informasi Penerimaan Siswa Baru Berbasis Web ( Studi Kasus: SMP Plus Babussalam Bandung ). Infotronik, 1(1), 54-63. 